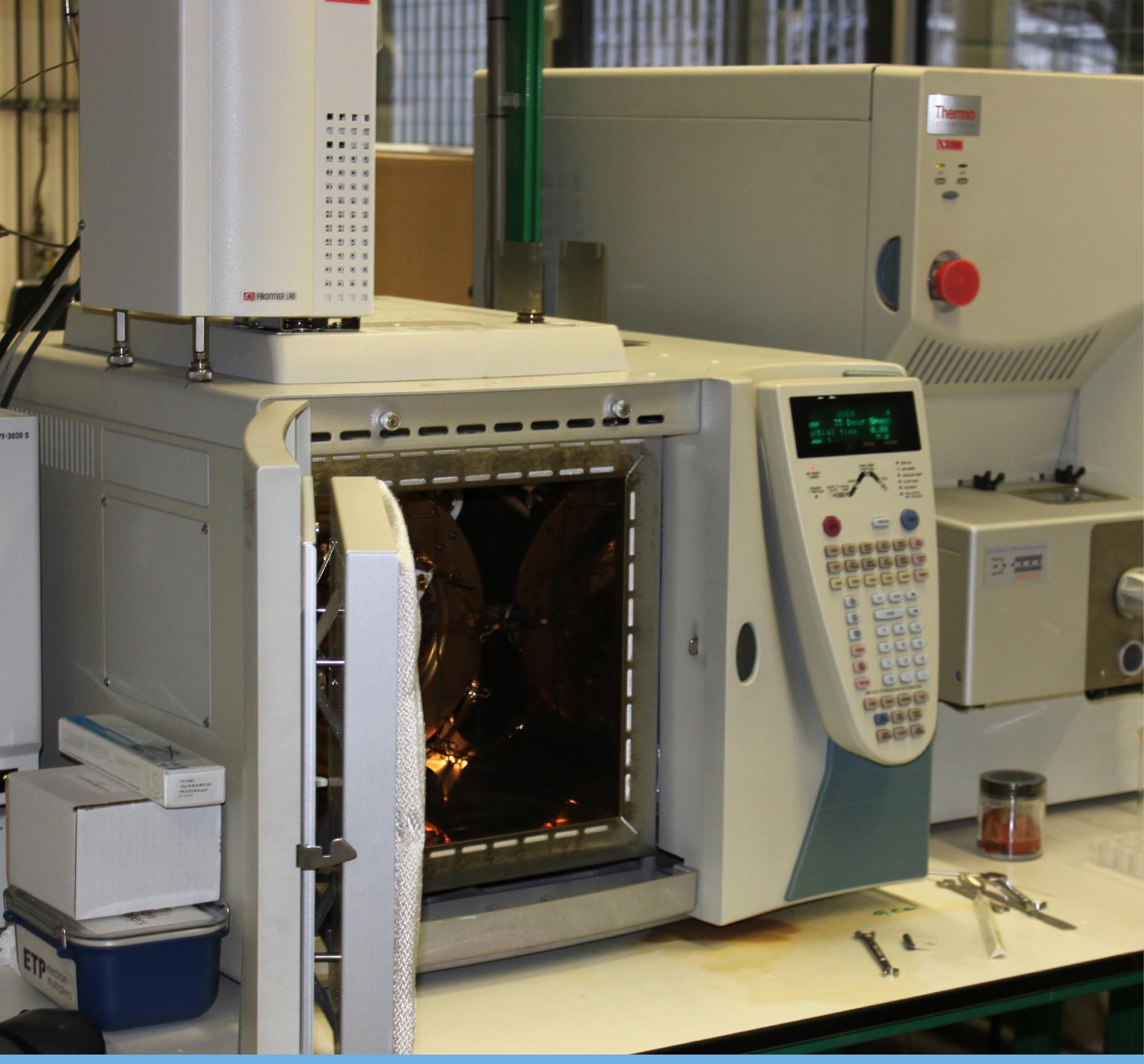

Pyrolyse ter bepaling van de kwaliteit van organische stof in mest 



\title{
Pyrolyse ter bepaling van de kwaliteit van organische stof in mest
}

Herman de Boer $^{1)}$, Karst Brolsma ${ }^{2)}$, Bas Fleurkens ${ }^{2)}$, Anneke Schoonbergen ${ }^{2)}$, Petra van Vliet ${ }^{2)}$

\author{
1) Wageningen Livestock Research \\ 2) Eurofins Agro
}

Dit onderzoek is uitgevoerd door Wageningen Livestock Research en Eurofins Agro, en gefinancierd uit de PPS Beter Bodembeheer (onderdeel 1b, Sturen op mestkwaliteit) (AF 16064, BO-47-001-006), met medefinanciering van ZuiveINL

Wageningen Livestock Research

Wageningen, maart 2020

Rapport 1240 
De Boer, H.C., Brolsma, K.M., Fleurkens, B.G.M., Schoonbergen, A., Van Vliet, P.C.J., 2020. Pyrolyse ter bepaling van de kwaliteit van organische stof in mest. Wageningen Livestock Research, Rapport 1240.

Dit rapport is gratis te downloaden op of op https://doi.org/10.18174/517478

www.wur.nl/livestock-research (onder Wageningen Livestock Research publicaties).

(C) 2018 Wageningen Livestock Research

Postbus 338, 6700 AH Wageningen, T 03174839 53, E info.livestockresearch@wur.nl, www.wur.nl/livestock-research. Wageningen Livestock Research is onderdeel van Wageningen University \& Research.

Wageningen Livestock Research aanvaardt geen aansprakelijkheid voor eventuele schade voortvloeiend uit het gebruik van de resultaten van dit onderzoek of de toepassing van de adviezen.

Alle rechten voorbehouden. Niets uit deze uitgave mag worden vermenigvuldigd en/of openbaar gemaakt worden door middel van druk, fotokopie, microfilm of op welke wijze dan ook zonder voorafgaande toestemming van de uitgever of auteur.

De certificering volgens ISO 9001 door DNV onderstreept ons kwaliteitsniveau. Op als onze onderzoeksopdrachten zijn de Algemene Voorwaarden van de Animal Sciences Group van D四 toepassing. Deze zijn gedeponeerd bij de Arrondissementsrechtbank Zwolle.

Wageningen Livestock Research Rapport 1240. 


\section{Inhoud}

$\begin{array}{ll}\text { Samenvatting } & 5\end{array}$

$\begin{array}{ll}\text { Introductie } & 7\end{array}$

1

$\begin{array}{ll}\text { Materiaal en methoden } & 9\end{array}$

1.1 Mestverzameling $\quad 9$

1.2 Standaardkenmerken mest 9

$\begin{array}{lll}1.3 & \text { Grondverzameling en grondsamenstelling } & 10\end{array}$

1.4 Incubatieproef voor meting $\mathrm{CO}_{2}$-respiratie 10

$\begin{array}{ll}1.5 & \text { Incubatieproef voor grondanalyse } \\ 1.6 & 10\end{array}$

$\begin{array}{lll}1.6 & \text { Meting pyrolyse GC-MS } & 10\end{array}$

$\begin{array}{lll}1.7 & \text { Berekeningen en statistische analyse } & 11\end{array}$

2

$\begin{array}{ll}\text { Resultaten } & 12\end{array}$

$2.1 \quad$ Standaardkenmerken mest 12

2.2 C-mineralisatie $\quad 12$

$\begin{array}{lll}2.3 \text { Pyrolyse } & 17\end{array}$

2.4 Relatie tussen C-mineralisatie en pyrolyseparameters $\quad 17$

3 Discussie $r$

3.1 Spreiding in C-mineralisatie tussen mesten $\quad 19$

3.2 Veranderingen in pyrolyseparameters tijdens incubatie 19

3.3 Verklaring van C-mineralisatie uit mesteigenschappen $\quad 20$

$\begin{array}{ll}\text { Conclusies } & \mathbf{2 1}\end{array}$

$\begin{array}{ll}\text { Dankwoord } & 22\end{array}$

$\begin{array}{ll}\text { Literatuur } & 23\end{array}$

$\begin{array}{ll}\text { Bijlage } & 24\end{array}$ 



\section{Samenvatting}

De kwaliteit van organische mest is belangrijk voor de Nederlandse landbouw. Een wezenlijk onderdeel van mestkwaliteit is de samenstelling van de organische stof (OS). Deze samenstelling bepaalt onder meer hoe snel de toegediende OS door het bodemvoedselweb kan worden afgebroken, en daarmee bijvoorbeeld de snelheid waarmee nutriënten uit de mest beschikbaar komen voor opname door gewassen. De OS-samenstelling bepaalt daarnaast ook hoeveel van de toegediende OS op termijn in de bodem overblijft en daar bijdraagt aan het gehalte stabiele OS. Dit gehalte is belangrijk voor bodemvruchtbaarheidsaspecten zoals het vasthouden van vocht en buffering van nutriënten. De snelheid van afbraak van de OS uit een mest geeft dus belangrijke informatie over de geschiktheid van deze mest om specifieke doelen te realiseren. Het is daarom belangrijk om inzicht te hebben in de afbraakpatronen van mest, niet alleen van verschillende soorten mest, maar ook van verschillende partijen binnen één soort.

Afbraakpatronen van OS kunnen relatief eenvoudig worden gemeten in incubatieproeven. Hierbij wordt mest gemengd met grond en wordt op een aantal tijdstippen de $\mathrm{CO}_{2}$-respiratie van het mengsel gemeten. Deze gegevens kunnen worden gebruikt om te berekenen hoeveel koolstof (C) er op een tijdstip door respiratie is verdwenen en hoeveel van de oorspronkelijk toegediende $C$ nog aanwezig is. De overblijvende hoeveelheid $C$ wordt hierbij gebruikt als een proxy (variabele) voor de overblijvende hoeveelheid OS. Dergelijke incubatieproeven zijn echter relatief duur en tijdrovend. Om verschillen in OS-kwaliteit bruikbaar te maken voor de praktijk, is er behoefte aan meetmethoden die op hoofdlijn dezelfde informatie geven als incubatieproeven, maar die snel en goedkoop kunnen worden gemeten aan de mest. Een mogelijk kansrijke methode is pyrolyse van de OS in mest. Bij pyrolyse wordt organisch materiaal onder zuurstofloze omstandigheden tot hoge temperatuur verhit, waarbij het materiaal uiteenvalt in een groot aantal verschillende fragmenten. Op basis van deze fragmenten kunnen organische verbindingen worden geïdentificeerd. Pyrolyse heeft als voordeel dat verschillende oS-kenmerken tegelijk kunnen worden geanalyseerd.

Om de geschiktheid van pyrolyse als meetmethode voor bepaling van OS-kwaliteit te beoordelen, zijn de afbraakpatronen van zes soorten mest vastgesteld in een incubatieproef en vervolgens gekoppeld aan hun pyrolyseresultaten. De zes soorten mest bestonden uit composten, runderdrijfmesten, digestaten van runderdrijfmest, varkensdrijfmesten, stromesten, en vrijloopstalmesten. Iedere mestsoort werd verzameld op vijf verschillende bedrijven, voor een totaal van 30 verschillende mesten. Doel van deze opzet was om een zo breed mogelijke variatie in samenstelling en kwaliteit van de OS te realiseren. De verzamelde mesten werden geanalyseerd op een aantal standaardkenmerken, gemengd met een zandgrond en ingezet in een incubatieproef bij constante temperatuur en vochtgehalte $\left(20^{\circ} \mathrm{C}, 168\right.$ dagen). Tijdens incubatie werden monsters verzameld op $\mathrm{t}=1$ dag (begin incubatie) en $t=168$ dagen (einde incubatie). Na drogen en malen werden deze monsters geanalyseerd met pyrolyse GC-MS. De gedetecteerde pyrolysefragmenten (op basis van pieken in het spectrum) werden per monster zover mogelijk geïdentificeerd, en op basis van deze fragmenten werden pyrolyseparameters onderscheiden. Met behulp van redundantie-analyse werd nagegaan of deze parameters verschilden tussen het begin en einde van de incubatieperiode. Daarna werd vastgesteld welke mestkenmerken de totale relatieve C-mineralisatie over de incubatieperiode het beste konden verklaren.

Uit de resultaten blijkt dat na 168 dagen incubatie de fractie overblijvende $\mathrm{C}$ voor de 30 mesten varieerde van $54 \%$ tot $94 \%$. Hiermee was de spreiding in afbreekbaarheid van de OS, en daarmee van verschillen in OS-kwaliteit, voldoende gerealiseerd. De fractie overblijvende $C$ aan het einde van de incubatieperiode was gemiddeld het laagst bij de runderdrijfmesten (63\%; range 55-80\%) en het hoogst bij de composten (90\%, range $82-94 \%$ ). Met de pyrolysemeting werden in de mengsels van grond en mest in totaal 272 pieken (pyrolysefragmenten) gedetecteerd. Hieruit konden 30 verschillende pyrolyseparameters worden onderscheiden. Deze set van parameters was aan het einde van de incubatieperiode significant verschillend vergeleken met het begin $(P<0,001)$. Bij de hoofdgroepen guaiacolen, syringolen, en lignine was er een toename van hun aandeel in de OS, terwijl er bij de koolhydraten, stikstofcomponenten, en alkanen+alkenen een afname was.

Met alleen de standaard mestkenmerken (DS, OS) kon maximaal $42 \%$ van de variantie in totale relatieve C-mineralisatie over de incubatieperiode verklaard worden; met alleen de pyrolyseparameters (verhouding alkanen/alkenen) maximaal 33\%. Bij gebruik van zowel de standaard 
mestkenmerken als de pyrolyseparameters kon maximaal $78 \%$ van de variantie verklaard worden, door: de verhouding alkanen tot alkenen (33\%), DS (12\%), OS (14\%), totaal guaiacolen (12\%), en de $\mathrm{pH}(7 \%)$. Meting van pyrolyseparameters aan mest gaf daarmee een aanzienlijke toename van de verklaarde variantie in C-mineralisatie uit deze mest. Pyrolyse lijkt daarmee een zinvolle aanvulling op bestaande bepalingen van OS-kwaliteit in mest. 


\section{Introductie}

De kwaliteit van organische mest is belangrijk voor de Nederlandse landbouw. Mestkwaliteit heeft veel aspecten en kan op verschillende manieren worden omschreven en gedefinieerd. Een wezenlijk onderdeel van mestkwaliteit is de samenstelling van de organische stof (OS). Deze samenstelling bepaalt onder meer hoe snel de toegediende OS door het bodemvoedselweb kan worden afgebroken, en daarmee bijvoorbeeld de snelheid waarmee nutriënten uit de mest beschikbaar komen voor opname door gewassen. De OS-samenstelling bepaalt daarnaast ook hoeveel van de toegediende OS op termijn in de bodem overblijft en daar bijdraagt aan het gehalte stabiele OS. Dit gehalte is belangrijk voor bodemvruchtbaarheidsaspecten zoals vochtvasthoudend vermogen en buffering van nutriënten. De snelheid van afbraak van de OS uit een mest geeft dus belangrijke informatie over de geschiktheid van deze mest om specifieke doelen te realiseren. Het is daarom belangrijk om inzicht te hebben in de afbraakpatronen van mest, niet alleen van verschillende soorten mest, maar ook van verschillende partijen binnen één soort.

Afbraakpatronen van OS kunnen relatief eenvoudig worden gemeten in incubatieproeven. Hierbij wordt mest gemengd met grond en wordt op een aantal tijdstippen de $\mathrm{CO}_{2}$-respiratie gemeten. Deze gegevens kunnen worden gebruikt om te berekenen hoeveel koolstof (C) er op een tijdstip door respiratie is verdwenen en hoeveel van de oorspronkelijk toegediende $C$ nog aanwezig is. De overblijvende hoeveelheid $C$ wordt hierbij gebruikt als een proxy (variabele) voor de overblijvende hoeveelheid OS.

Dergelijke incubatieproeven zijn echter relatief duur en tijdrovend; een incubatieproef duurt meestal een aantal maanden. Om verschillen in de kwaliteit van OS in mest bruikbaar te maken voor de praktijk, is er behoefte aan parameters die op hoofdlijn dezelfde informatie geven als incubatieproeven, maar die snel en goedkoop kunnen worden gemeten. De mogelijke geschiktheid van een snelle meetmethode kan worden beoordeeld door deze methode te relateren aan het gemeten afbraakpatroon uit een incubatieproef, en vervolgens deze relatie te beoordelen. Bij een goede relatie, en een goede herhaalbaarheid, kan de snelle meetmethode vervolgens worden ingezet om een partij mest te karakteriseren op OS-kwaliteit. De praktijk kan vervolgens met deze informatie onderbouwde beslissingen nemen over de inzetbaarheid van deze partij mest.

Een mogelijk kansrijke meetmethode is pyrolyse van de OS in mest. Bij pyrolyse wordt organisch materiaal onder zuurstofloze omstandigheden tot hoge temperatuur verhit, waarbij het uiteenvalt in een groot aantal verschillende fragmenten. Op basis van deze fragmenten kunnen organische verbindingen worden geïdentificeerd. Pyrolyse heeft als voordeel dat verschillende OS-kenmerken tegelijk kunnen worden geanalyseerd. Om de geschiktheid van pyrolyse als meetmethode te beoordelen, is een experiment uitgevoerd waarin de afbraakpatronen van mest zijn gemeten in een incubatieproef en vervolgens zijn gekoppeld aan hun pyrolyseresultaten. De opzet, uitvoering, resultaten, en interpretaties van dit onderzoek zijn beschreven in het voorliggende rapport. 


\section{Materiaal en methoden}

\section{$1.1 \quad$ Mestverzameling}

Voor het onderzoek werden zes soorten mest verzameld, per soort op vijf verschillende bedrijven, voor een totaal van 30 partijen mest. Het doel van deze opzet was om een brede spreiding in OSsamenstelling van mest te krijgen. De zes mestsoorten waren:
1. Composten
2. Digestaten van runderdrijfmest
3. Runderdrijfmesten
4. Varkensdrijfmesten
5. Strostalmesten
6. Vrijloopstalmesten/-composten

De vijf partijen per mestsoort kunnen als volgt nog verder worden beschreven:

1. Compost: 2 groencomposten, 1 compostaarde, 1 GFT-compost en 1 champost

2. Digestaat: 3 digestaten uit monovergisting en 2 uit co-vergisting

3. Runderdrijfmest: 3 mesten met relatief veel gras in het rantsoen en 2 met relatief veel snijmaïs in het rantsoen

4. Varkensdrijfmest: 2 zeugenmesten en 3 vleesvarkensmesten ( 2 met droogvoer en 1 met brijvoer in het rantsoen)

5. Strostalmest: $\quad 3$ relatief jonge en 2 relatief oude strostalmesten, waaronder 2 vleesstierenmesten en 1 paardenstromest. Beide vleesstierenmesten werden verzameld op 1 bedrijf. Hierbij werd zowel een 'jonge' mest uit de stal als een 'oude' mest vanaf de mesthoop buiten verzameld

6. Vrijloopstalmest: 2 mesten met houtsnippers als strooisel, 1 met grovere houtdelen, 1 met stro, en 1 met divers organisch materiaal

De mestverzameling vond plaats van april $\mathrm{t} / \mathrm{m}$ juli 2017. Op ieder bedrijf werd een mestmonster van tenminste $4 \mathrm{~kg}$ verzameld. Dit monster werd goed gemengd en onderverdeeld in 5 submonsters van ieder $0,8 \mathrm{~kg}$. Deze submonsters werden bewaard bij $-20^{\circ} \mathrm{C}$ tot het moment van gebruik.

\subsection{Standaardkenmerken mest}

De verzamelde mesten werden door het Chemisch Biologisch Laboratorium Bodem (CBLB) in Wageningen geanalyseerd op 10 kenmerken (standaardkenmerken): $\mathrm{pH}$, drogestof, organische stof, $\mathrm{NH}_{4}-\mathrm{N}, \mathrm{NO}_{3}-\mathrm{N}, \mathrm{N}$-totaal, P-totaal, K-totaal, C-totaal en S-totaal. De pH werd gemeten met een standaard electrode; bij drijfmest in de verse mest en bij vaste mest na 1:5 verdunning met demiwater. Drogestof werd bepaald door 24 uur drogen bij $105^{\circ} \mathrm{C}$, en organische stof door bepaling van het gloeiverlies ( 3 uur bij $550^{\circ} \mathrm{C}$ ). $\mathrm{NH}_{4}-\mathrm{N}$ en $\mathrm{NO}_{3}-\mathrm{N}$ werden bepaald met SFA, na toevoeging van 1 $\mathrm{M} \mathrm{KCl}$ aan de verse mest, centrifugatie, verdunning en filtratie. $\mathrm{N}$-totaal en $\mathrm{P}$-totaal werden bepaald met ICP-AES, en K-totaal met SFA, na destructie van verse mest met zwavelzuur en salicylzuur en de toevoeging van selenium en waterstofperoxide, bij een temperatuur van $100^{\circ} \mathrm{C}$. C-totaal werd bepaald met een $\mathrm{CN}$ analyzer, na drogen van de mest bij $70^{\circ} \mathrm{C}$ en malen op $50 \mu \mathrm{m}$. S-totaal werd bepaald met ICP-AES, na drogen van de mest bij $70^{\circ} \mathrm{C}$, toevoeging van salpeterzuur en zoutzuur, en destructie van het mengsel in een magnetron. 


\subsection{Grondverzameling en grondsamenstelling}

De grond voor de incubatieproef werd verzameld op 17 juli 2017, op een perceel waar voor het tweede jaar snijmaïs (Zea mays spp. mays) werd verbouwd, na eerder drie jaar grasland. De grond bestond uit zwak lemig, matig fijn zand, en werd verzameld tot $10 \mathrm{~cm}$ diepte, in het midden tussen de rijen planten. Omdat er gras was ondergezaaid bevatte de verzamelde grond een kleine hoeveelheid graswortels. De verzamelde grond werd diezelfde dag vervoerd naar Wageningen en opgeslagen bij $4^{\circ} \mathrm{C}$. Op 18 juli werd een partij van deze grond gemengd, gezeefd over een $5 \mathrm{~mm}$ zeef, bemonsterd voor analyse van de samenstelling, en daarna gebruikt voor het inzetten van de incubatieproef. De grond had de volgende samenstelling (na drogen bij $40^{\circ} \mathrm{C}$ ): $\mathrm{pH}-\mathrm{KCl} 5,5, \mathrm{pH}$-water 6,4, OS 6,4\%,

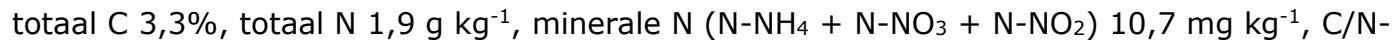
verhouding 17,4, P-Al $47 \mathrm{mg} \mathrm{P}_{2} \mathrm{O}_{5} 100^{-1} \mathrm{~g}$, en $\mathrm{K}-\mathrm{HCl} 11 \mathrm{mg} \mathrm{K} \mathrm{O}_{2} 100^{-1} \mathrm{~g}$. De granulaire samenstelling (na drogen bij $105^{\circ} \mathrm{C}$ ) was: $4 \%$ klei, $7 \%$ silt, en $82 \%$ zand.

\subsection{Incubatieproef voor meting $\mathrm{CO}_{2}$-respiratie}

De incubatieproef werd uitgevoerd door het CBLB te Wageningen en ingezet op 18 juli 2017. Voor deze proef werden glazen flessen $(\varnothing 6,9 \mathrm{~cm} ; 575 \mathrm{ml}$ ) gevuld met alleen verse zandgrond (controle) of verse zandgrond gemixt met de verschillende mesten. De verse grond $(180 \mathrm{~g})$ werd gemixt met $15 \mathrm{~g}$ verse mest en er werd gedemineraliseerd water toegediend tot $60 \%$ van de vloeigrens van de grond (341 $\mathrm{g}$ water $\mathrm{kg}^{-1}$ droge grond). Hierbij werd gecorrigeerd voor de al toegediende hoeveelheid water met mest. Na het vullen werden de flessen gewogen, afgesloten met een prop watten, en gedurende 168 dagen weggezet bij $20^{\circ} \mathrm{C}$, in het donker. De controle werd in viervoud ingezet en de behandelingen in tweevoud. De $\mathrm{CO}_{2}$-respiratie van de flessen werd gemeten met een Innova 1412 foto-akoestische gasmonitor, 1, 3, 7, 14, 28, 56, 84, 112, 140 en 168 dagen na het inzetten. Bij iedere meting werd de $\mathrm{CO}_{2}$-concentratie ( $\mathrm{ppm}$ ) in de fles gemeten aan het einde van een accumulatieperiode, en werd deze gecorrigeerd voor de $\mathrm{CO}_{2}$-concentratie in de omgevingslucht ( beginconcentratie in de flessen). De accumulatieperiode werd tijdens de proef verlengd, van 0,5 uur bij de eerste meting tot 16 uur bij de laatste meting, om de $\mathrm{CO}_{2}$-concentratie tussen de 1000 en $10.000 \mathrm{ppm}$ te houden. Na iedere meting werd gedemineraliseerd water toegevoegd om het oorspronkelijke vochtgehalte in de flessen te herstellen. Na het einde van de incubatieperiode $(t=168$ dagen) werd van één fles per behandeling het luchtvolume ('headspace') gravimetrisch bepaald. Van de andere fles werd de inhoud gedroogd bij $40^{\circ} \mathrm{C}$, gezeefd op $2 \mathrm{~mm}$, en opgeslagen.

\subsection{Incubatieproef voor grondanalyse}

Parallel aan de incubatieproef met flessen werd ook een incubatieproef met polyethyleen zakjes ingezet (Velthof en Oenema 2010), met als doel om de in de flessenproef ingezette grondmestmengsels te analyseren op samenstelling. De incubatieproef met (luchtdoorlatende) polyethyleen zakjes werd onder dezelfde condities uitgevoerd als de incubatieproef met flessen, met dezelfde behandelingen, en met menging van dezelfde hoeveelheden grond en mest. De controle werd echter niet in viervoud maar in duplo uitgevoerd, en de behandelingen met toediening van mest niet in duplo maar in enkelvoud. Op dag 1 werden van alle behandelingen de relevante zakjes uitgehaald, werd de inhoud gedroogd bij $40^{\circ} \mathrm{C}$, gezeefd op $2 \mathrm{~mm}$, en opgeslagen.

\subsection{Meting pyrolyse GC-MS}

De verzamelde en gedroogde grondmonsters van $t=1$ dag (begin incubatie, zakjes) en $t=168$ dagen (einde incubatie, flessen) werden door Eurofins Agro (Wageningen) geanalyseerd met pyrolyse GCMS. Deze analyse werd uitgevoerd met een Py-3030S pyrolysator $\left(550^{\circ} \mathrm{C}\right.$ ) met Py-1020ET auto-shot sampler (Frontier Lab, Fukushima, Japan), die was verbonden met een GC-MS systeem (Trace GC Ultra) met een drievoudige vierpolige massaspectrometer (Thermo Scientific, Waltham MA, USA). De gedetecteerde pyrolysefragmenten (op basis van pieken in het gemeten spectrum) werden per monster zover mogelijk geïdentificeerd, en het totale geïdentificeerde gebied werd uitgedrukt als 
$100 \%$ totale ionenstroom (TIC). De relatieve hoeveelheid van elke piek werd vervolgens uitgedrukt als percentage van TIC. Geïdentificeerde pyrolysefragmenten werden verdeeld in hoofdgroepen, zoals alifatische verbindingen, lignine, stikstofhoudende verbindingen (inclusief chitine), en koolhydraten. Deze hoofdgroepen werden verder onderverdeeld in diverse componenten, gebaseerd op Van Nierop (2001, 2005), Buurman (2007, 2009), en Schellekens (2013).

\subsection{Berekeningen en statistische analyse}

Incubatieproef $\mathrm{CO}_{2}$-respiratie

Voor de incubatieproef werd per fles/behandeling berekend hoeveel $\mathrm{C}$ er bij de start van de proef was toegediend met grond en mest. Vervolgens werd per fles per meettijdstip de $\mathrm{CO}_{2}$-flux berekend, op basis van de begin- en eindconcentratie $\mathrm{CO}_{2}$. Hierbij werd een molair volume $\left(\mathrm{V}_{\mathrm{m}}\right)$ van $24,04 \mathrm{~L} \mathrm{~mol}^{-1}$ $\left(20^{\circ} \mathrm{C}\right)$ aangenomen. Met lineaire integratie van de $\mathrm{CO}_{2}$-flux over de tijd werd per fles berekend hoeveel $C$ er tussen de tijdstippen respireerde, en hoeveel er per tijdstip nog in de fles over was. Deze hoeveelheid werd uitgedrukt als fractie (\%) van de oorspronkelijke hoeveelheid aanwezige $\mathrm{C}$ in grond + mest of in alleen mest (na correctie voor de hoeveelheid overblijvende $\mathrm{C}$ uit alleen de zandgrond). De fractie overblijvende $C$ is een proxy (variabele) voor overblijvende OS; deze termen worden in de rapportage naast elkaar gebruikt. De berekende fracties overblijvende $C$ van alle 30 mesten op alle meettijdstippen werden gezamenlijk statistisch geanalyseerd met behulp van de ANOVA-procedure voor herhaalde waarnemingen in statistisch pakket Genstat (19e editie; VSNI, Hemel Hempstead, UK). Hierbij bestond de 'Treatment structure' uit Mestnr., de 'Block structure' uit Herhalingsnr., en de 'Timepointfactor' uit het volgnummer van de meettijdstippen ( $1 \mathrm{t} / \mathrm{m} 11)$.

\section{Pyrolyse GC-MS}

Voor de 30 geïdentificeerde pyrolyseparameters is nagegaan of deze verschilden tussen het begin en einde van de incubatieperiode. Hiervoor werd gebruik gemaakt van redundantie-analyse (RDA) in statistisch pakket CANOCO 5, met tijd ( $t=1 \mathrm{~d}$ en $\mathrm{t}=168 \mathrm{~d}$ ) als verklarende variabele en de pyrolyseparameters als de te verklaren variabelen. Daarna werd vastgesteld welke mestkenmerken de totale relatieve C-mineralisatie (uit grond + mest) over de hele incubatieperiode het beste konden verklaren. Hierbij werden alle 41 mestkenmerken (10 standaardkenmerken; 30 pyrolyseparameters op $t=1 \mathrm{~d}$ ) als verklarende variabelen opgenomen in een RDA-analyse. De selectie van de mestkenmerken werd hierbij stapsgewijs doorgevoerd. Daardoor werden de kenmerken geselecteerd die een sterk effect hadden op de totale mineralisatie, en werd tegelijk ook de door deze kenmerken verklaarde variantie gesorteerd. Mestkenmerken werden alleen geselecteerd als hun opname een significante toename in verklaarde variantie gaf $(P<0,05)$. De stapsgewijze selectie werd eerst gedaan voor de 10 standaardkenmerken, daarna voor de 30 pyrolyseparameters, en tenslotte voor alle 41 mestkenmerken gezamenlijk. De geselecteerde verklarende mestkenmerken werden daarna opgenomen in een lineair regressiemodel om de bijdrage van elk kenmerk te bepalen. Met behulp van dit regressiemodel is vervolgens per mest de totale relatieve C-mineralisatie geschat, en is deze modelwaarde afgezet tegen de gemeten waarde. 


\section{Resultaten}

\subsection{Standaardkenmerken mest}

De standaardkenmerken van de 30 gebruikte mesten zijn gegeven in Tabel 1.

Tabel 1 Standaardkenmerken van de 30 verzamelde mesten (in $\mathrm{g} \mathrm{kg}^{-1}$ vers product, behalve $\mathrm{pH}$ en berekende $C / N$-verhouding).

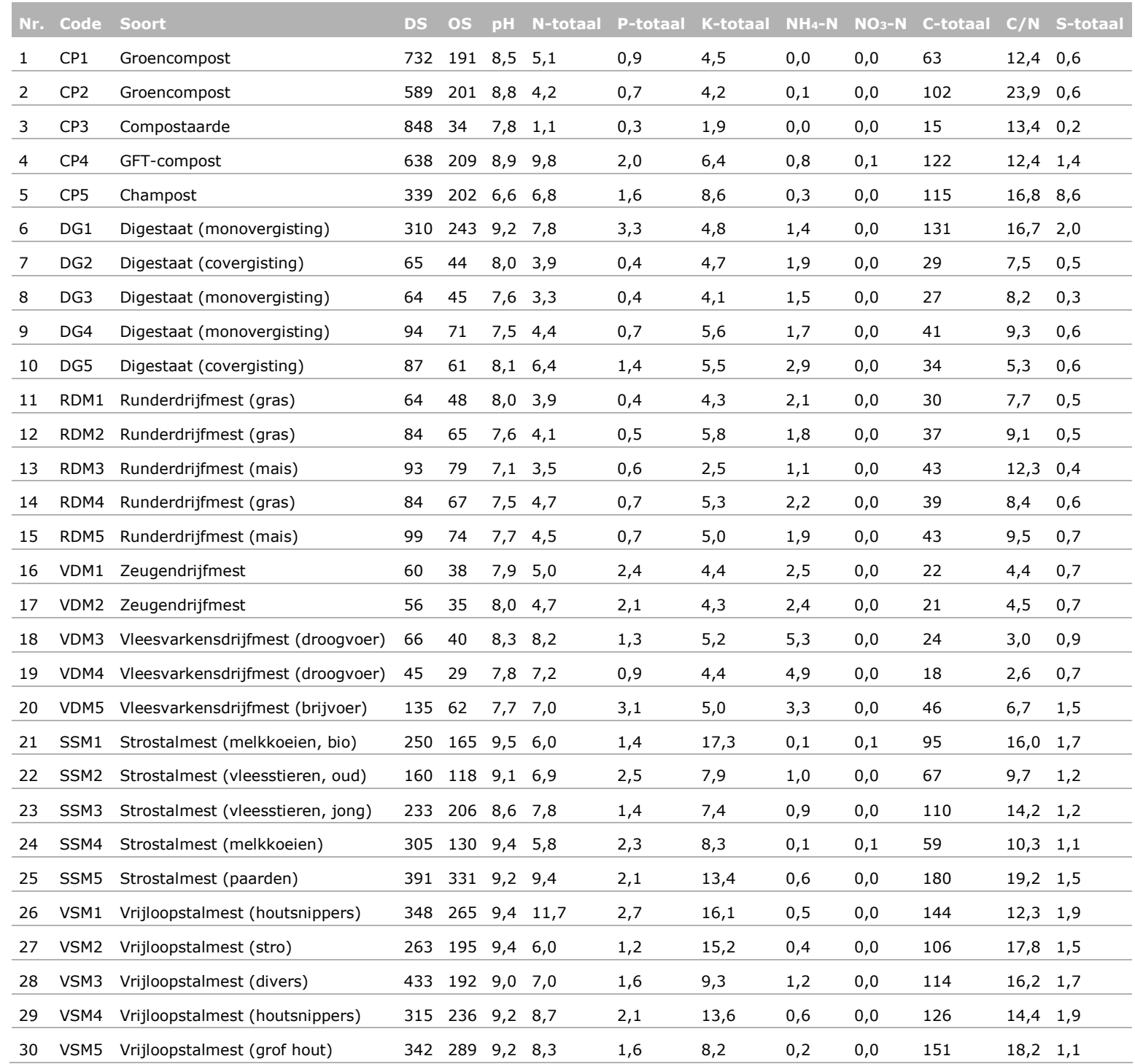

\section{$2.2 \quad$ C-mineralisatie}

Uit de statistische analyse bleek dat de fractie overblijvende $\mathrm{C}$ uit een toegediende individuele mest afhankelijk was van zowel de mest als het meettijdstip $(P<0,001)$; het kleinste significante verschil (LSD; $P \leq 0,05$ ) in overblijvende $C$ was $1,9 \%$ bij vergelijking van willekeurige combinaties van mest en meettijdstip, en $1,4 \%$ bij vergelijking tussen meettijdstippen per individuele mest. 
De OS in de zandgrond brak langzaam af; na 168 dagen incubatie was er nog 98,3\% over van de oorspronkelijke aanwezige hoeveelheid C (Figuur 1).

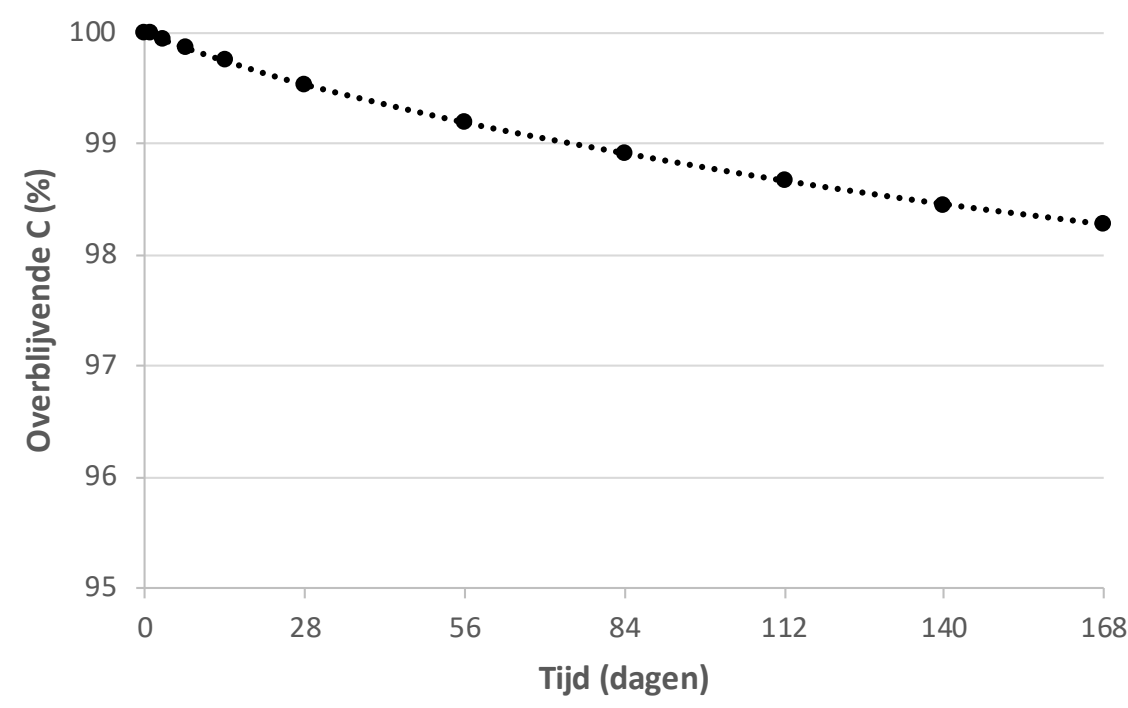

Figuur 1 Verloop van de fractie overblijvende C (\%) in de zandgrond tijdens incubatie onder gecontroleerde omstandigheden.

De $\mathrm{C}$ in toegediende champost mineraliseerde sneller dan de $\mathrm{C}$ in de andere vier composten, met een fractie overblijvende $\mathrm{C}$ na 168 dagen van $82 \%$ (Figuur 2). Bij de andere composten varieerde deze fractie op dat tijdstip van $89 \%$ tot $94 \%$.

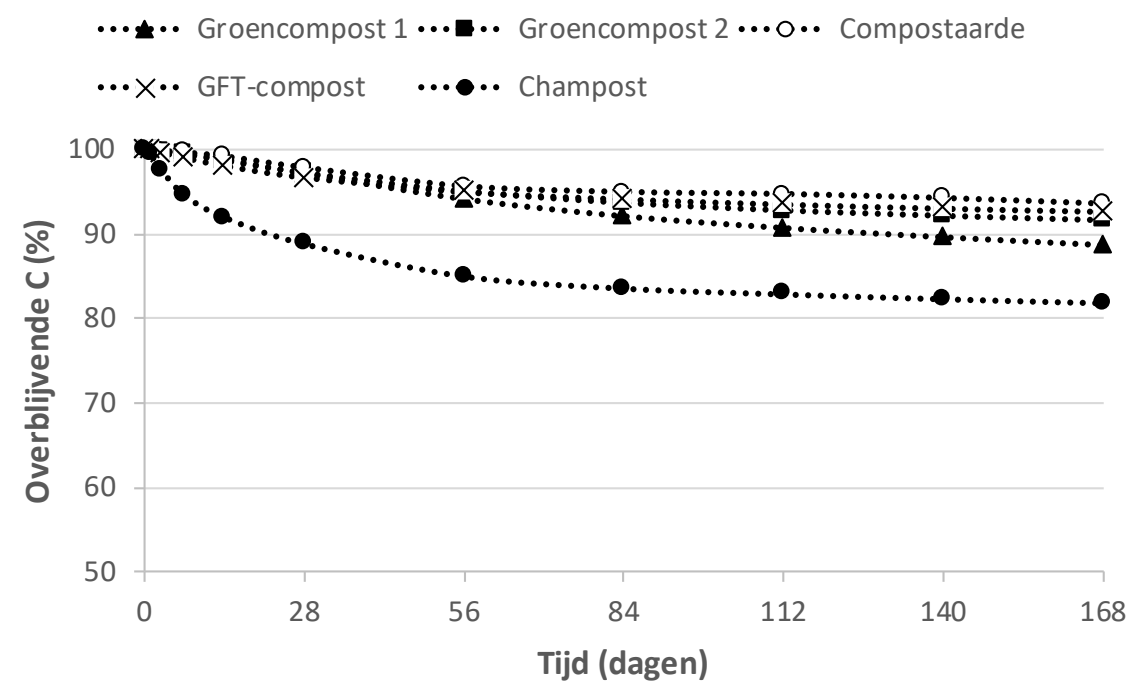

Figur 2 Verloop van de fractie overblijvende $C(\%)$ van vijf composten tijdens incubatie met zandgrond onder gecontroleerde omstandigheden. Resultaten voor de composten zijn na aftrek van de bijdrage van de zandgrond. 
Bij vier van de vijf digestaten varieerde de fractie overblijvende C na 168 dagen incubatie van $80 \%$ tot $88 \%$ (Figuur 3). Het digestaat van bedrijf 4 week duidelijk af, met een overblijvende fractie van $66 \%$. Bij digestaten DG1 en DG4 ging de C-mineralisatie door tot aan het einde van de incubatieperiode, terwijl bij de andere digestaten de mineralisatie tijdens de incubatieperiode (vrijwel) tot stilstand kwam.

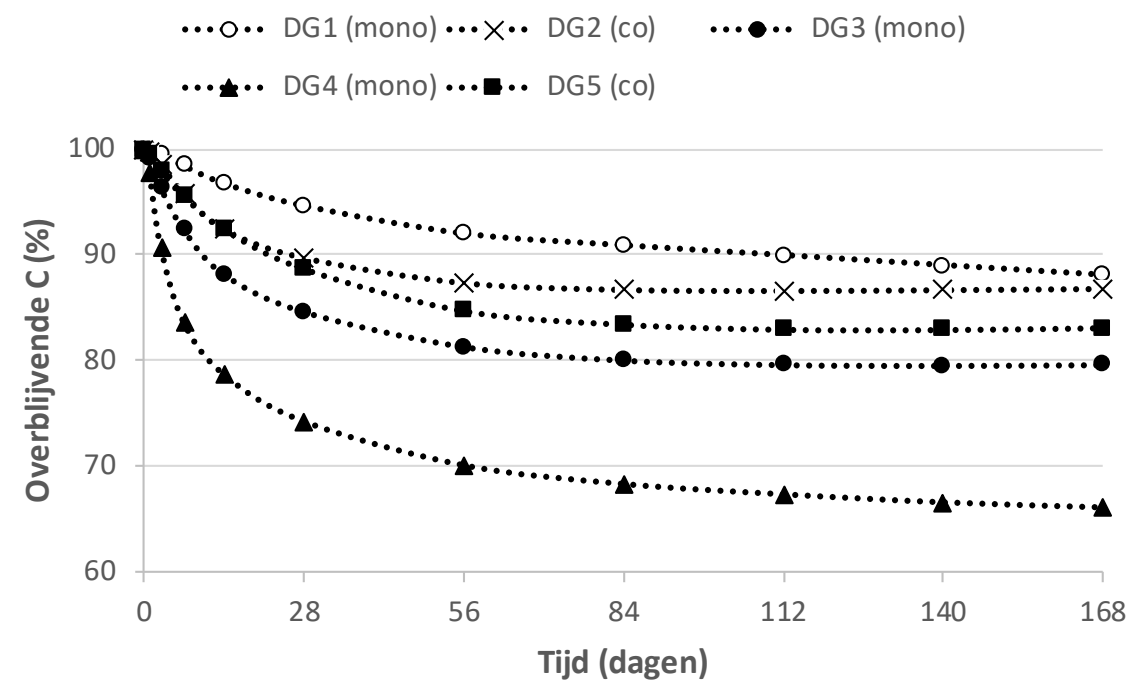

Figuur 3 Verloop van de fractie overblijvende C (\%) van vijf digestaten (DG) uit mono- of covergisting van runderdrijfmest tijdens incubatie met zandgrond onder gecontroleerde omstandigheden. Resultaten van de digestaten zijn na aftrek van de bijdrage van de zandgrond.

Bij de runderdrijfmesten varieerde de fractie overblijvende $\mathrm{C}$ na 168 dagen incubatie van $55 \%$ tot 79\% (Figuur 4). Bij RDM1 kwam de mineralisatie na 112 dagen tot stilstand, op een niveau van 79\% overblijvende $\mathrm{C}$, terwijl deze bij de andere vier drijfmesten nog (langzaam) doorging. De afname in fractie overblijvende $C$ tussen $t=112$ en $t=168$ dagen varieerde bij deze vier drijfmesten van 0,6 tot 1,3 procentpunt en was daarmee klein.

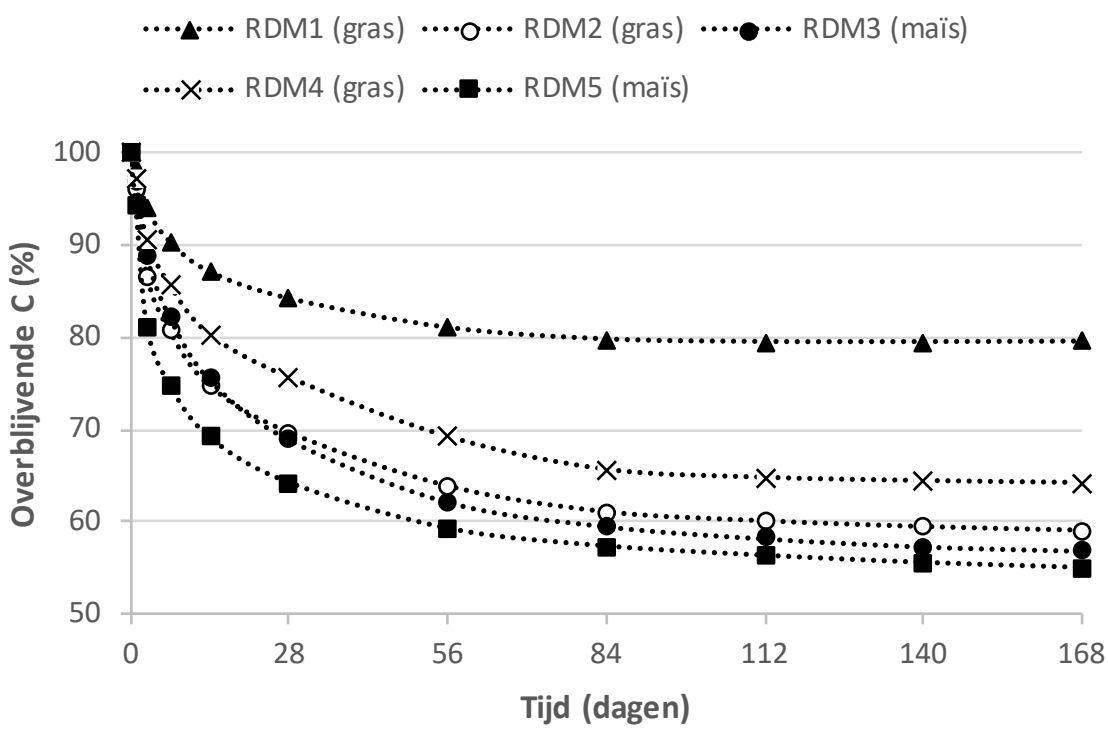

Figuur 4 Verloop van de fractie overblijvende C (\%) van vijf runderdrijfmesten (RDM), geproduceerd met relatief veel gras of snijmaïs in het rantsoen, tijdens incubatie met zandgrond onder gecontroleerde omstandigheden. Resultaten van de runderdrijfmesten zijn na aftrek van de bijdrage van de zandgrond. 
Bij de varkensdrijfmesten varieerde de fractie overblijvende $\mathrm{C}$ na 168 dagen incubatie van $68 \%$ tot 85\% (Figuur 5). Bij drie van de vijf mesten kwam de mineralisatie tijdens incubatie tot stilstand; bij één mest ging de mineralisatie door (VDM5), en bij één mest (VDM4) leek de mineralisatie na 84 dagen licht negatief te worden. Hierbij leek de fractie overblijvende $C$ tussen $t=84 \mathrm{~d}$ en $t=168 \mathrm{~d}$ toe te nemen; deze toename was met 1 procentpunt niet significant.

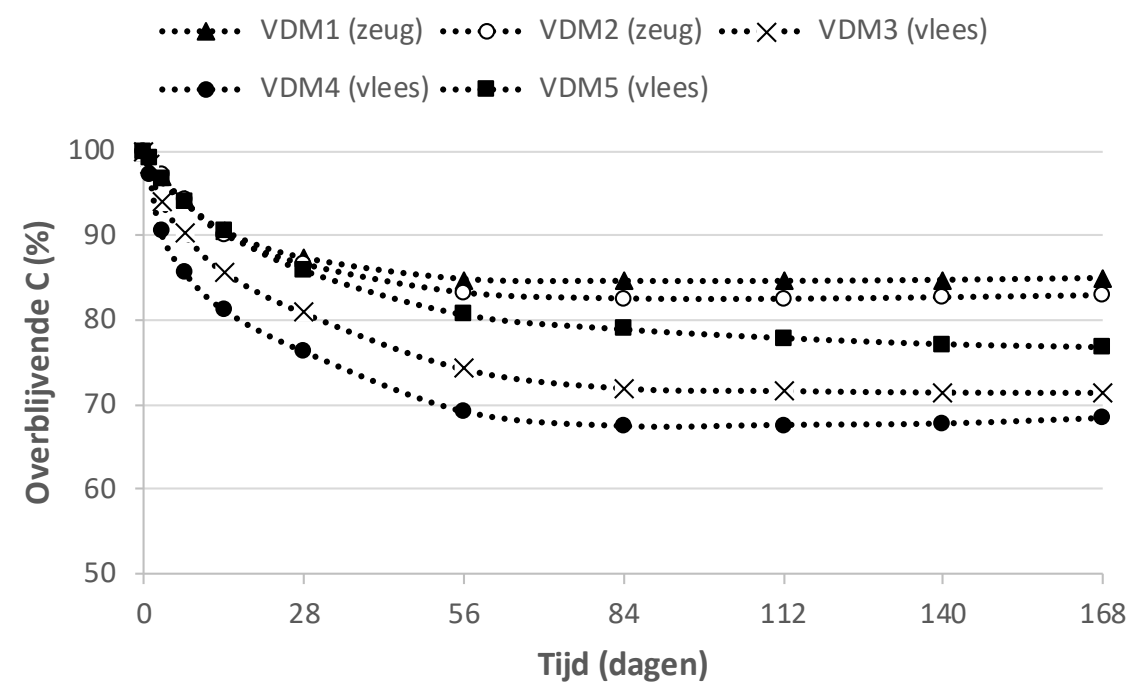

Figuur 5 Verloop van de fractie overblijvende C (\%) van vijf varkensdrijfmesten (VDM), afkomstig van zeugen of vleesvarkens, tijdens incubatie met zandgrond onder gecontroleerde omstandigheden. Resultaten van de varkensdrijfmesten zijn na aftrek van de bijdrage van de zandgrond.

Bij de strostalmesten varieerde de fractie overblijvende C na 168 dagen incubatie van $54 \%$ tot $87 \%$ (Figuur 6). 'Jonge' vleesstierenmest (SSM3) had een duidelijk snellere C-mineralisatie dan 'oude' vleesstierenmest (SSM2).

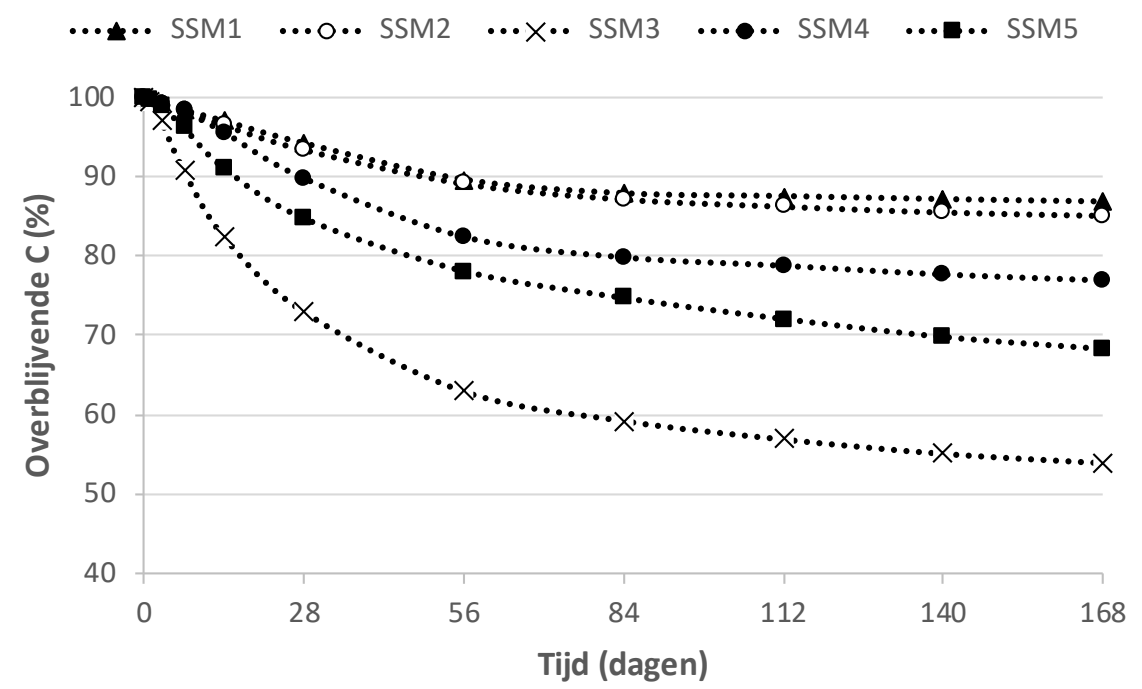

Figuur 6 Verloop van de fractie overblijvende C (\%) van vijf strostalmesten (SSM) tijdens incubatie met zandgrond onder gecontroleerde omstandigheden. Resultaten van de strostalmesten zijn na aftrek van de bijdrage van de zandgrond. 
Bij de vrijloopstalmesten varieerde de overblijvende fractie C na 168 dagen incubatie van $65 \%$ tot 89\% (Figuur 7). Vrijloopstalmest met houtsnippers als strooisel (VSM1, VSM4) mineraliseerde langzamer dan vrijloopstalmest met wat grovere houtdelen als strooisel (VSM5). De vrijloopstalmest met stro als strooisel (VSM2) mineraliseerde relatief snel. Deze mest kan overigens ook gezien worden als een strostalmest.

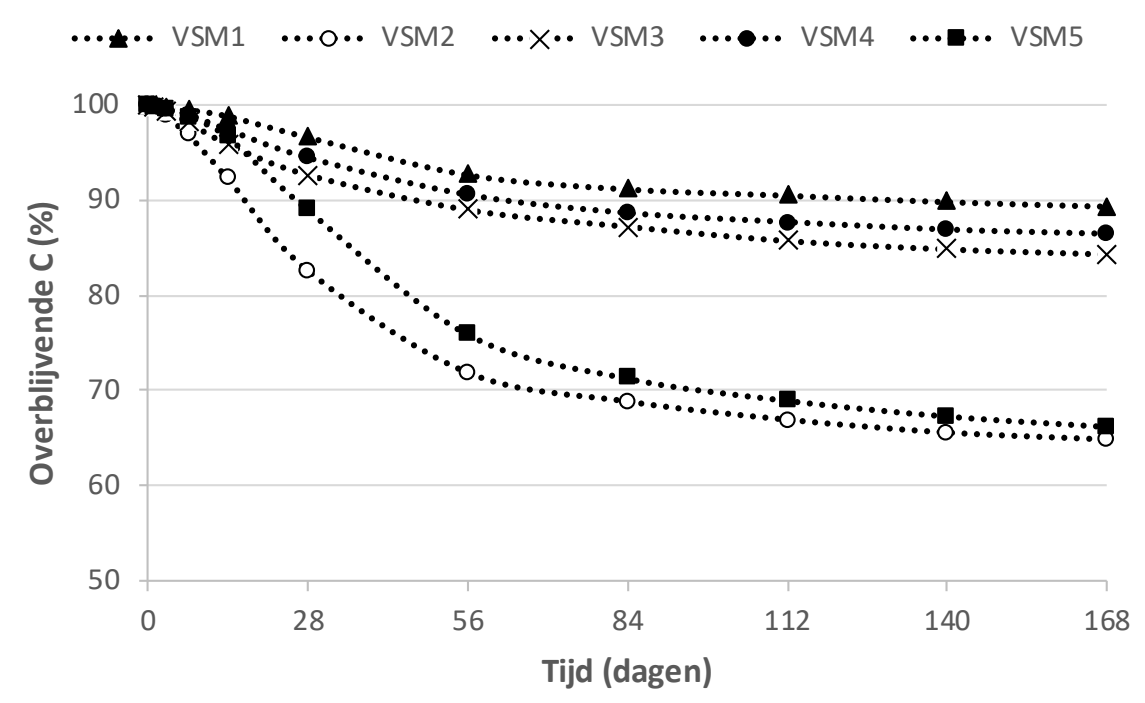

Figuur $7 \quad$ Verloop van de fractie overblijvende C (\%) van vijf vrijloopstalmesten (VSM) tijdens incubatie met een zandgrond onder gecontroleerde omstandigheden. Resultaten van de vrijloopstalmesten zijn na aftrek van de bijdrage van de zandgrond. 


\subsection{Pyrolyse}

Tijdens pyrolyse van de mengsels van grond en mest werden in totaal 272 verschillende pieken (pyrolysefragmenten) gedetecteerd. Met deze pieken konden 30 verschillende pyrolyseparameters (hoofdgroepen en componenten) worden onderscheiden (Tabel 2). Deze set van parameters, gemeten in de mengsels van grond en mest, was aan het einde van de incubatieperiode significant verschillend vergeleken met het begin $(P<0,001)$. Voor de hoofdgroepen guaiacolen, syringolen, en lignine was er een toename van hun aandeel in de OS, terwijl er voor koolhydraten, stikstofcomponenten en alkanen + alkenen een afname was.

Tabel 2 Overzicht van de geïdentificeerde pyrolyseparameters, uitgedrukt als aandeel van de 'Total Ion Current' (TIC), als aandeel van een hoofdgroep, of in verhouding tot een andere parameter. Per parameter is de gemiddelde relatieve waarde (voor alle mesten, $n$ = 30) en de bijbehorende standaardfout gegeven voor de meting op dag 1 (begin incubatie) en dag 168 (einde incubatie).

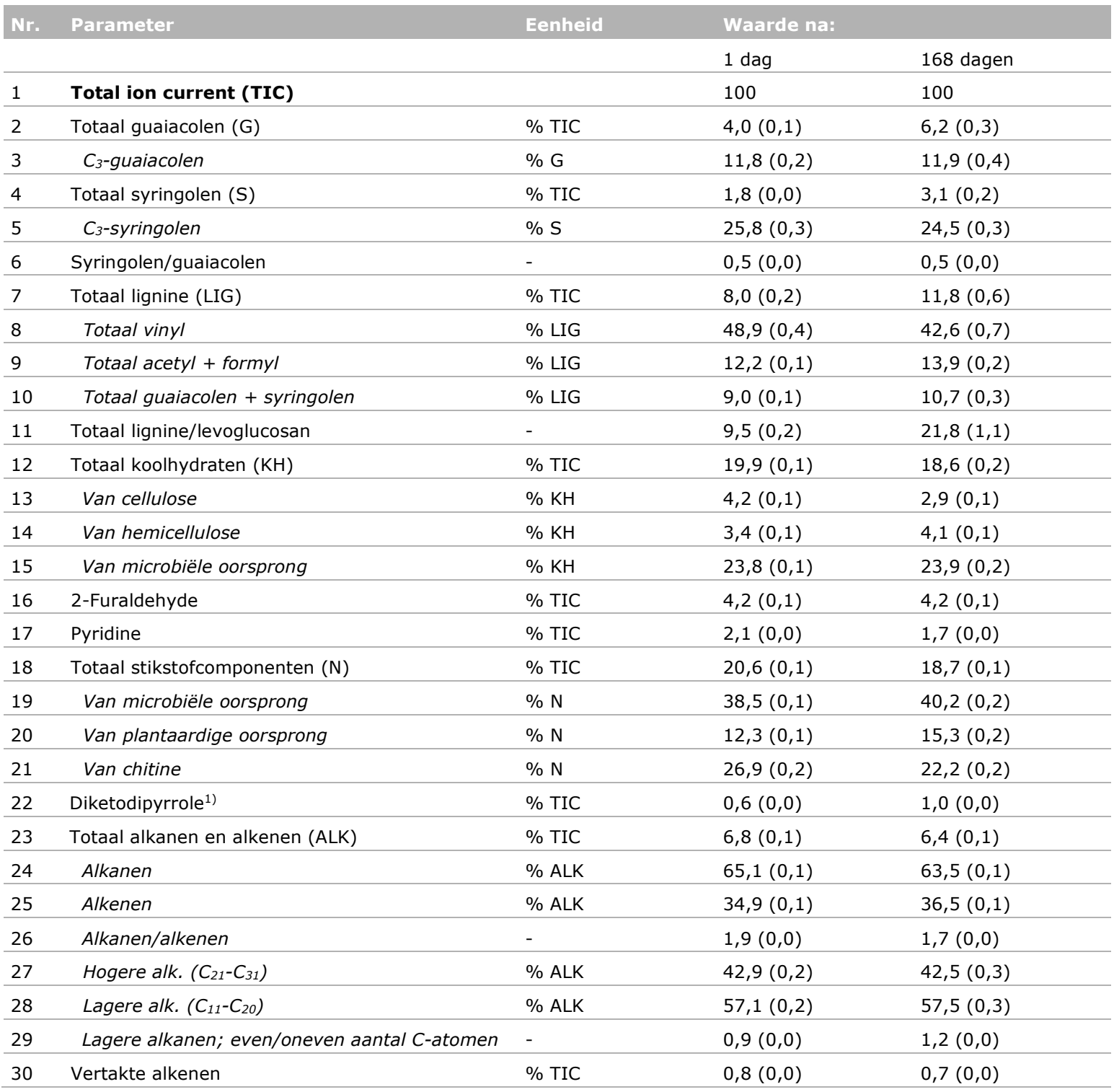

1) van zowel microbiële als plantaardige oorsprong

\subsection{Relatie tussen C-mineralisatie en pyrolyseparameters}

Uit de stapsgewijze redundantie-analyse volgt dat er met alleen de standaard mestkenmerken maximaal $42 \%$ van de variantie in C-mineralisatie verklaard kon worden $(P<0,05)$, door de kenmerken DS en OS (Tabel 3). Met alleen de pyrolyseparameters kon maximaal 33\% van de 
variantie verklaard worden $(P<0,05)$, door de verhouding alkanen/alkenen. Bij combinatie van alle mestkenmerken kon maximaal $78 \%$ van de totale mineralisatie verklaard worden $(P<0,05)$, door de verhouding alkanen/alkenen, DS, OS, totaal guaiacolen, en $\mathrm{pH}$. Aanvullende meting van de verhouding alkanen/alkenen en totaal guaiacolen door middel van pyrolyse gaf daarmee een aanzienlijke toename van de verklaarde variantie in C-mineralisatie.

Tabel 3 Verklaarde variantie (\%) in C-mineralisatie en P-waarden voor geselecteerde mestkenmerken na redundantie-analyse, bij gebruik van alleen de standaard mestkenmerken, alleen de pyrolyseparameters, of beide groepen gecombineerd.

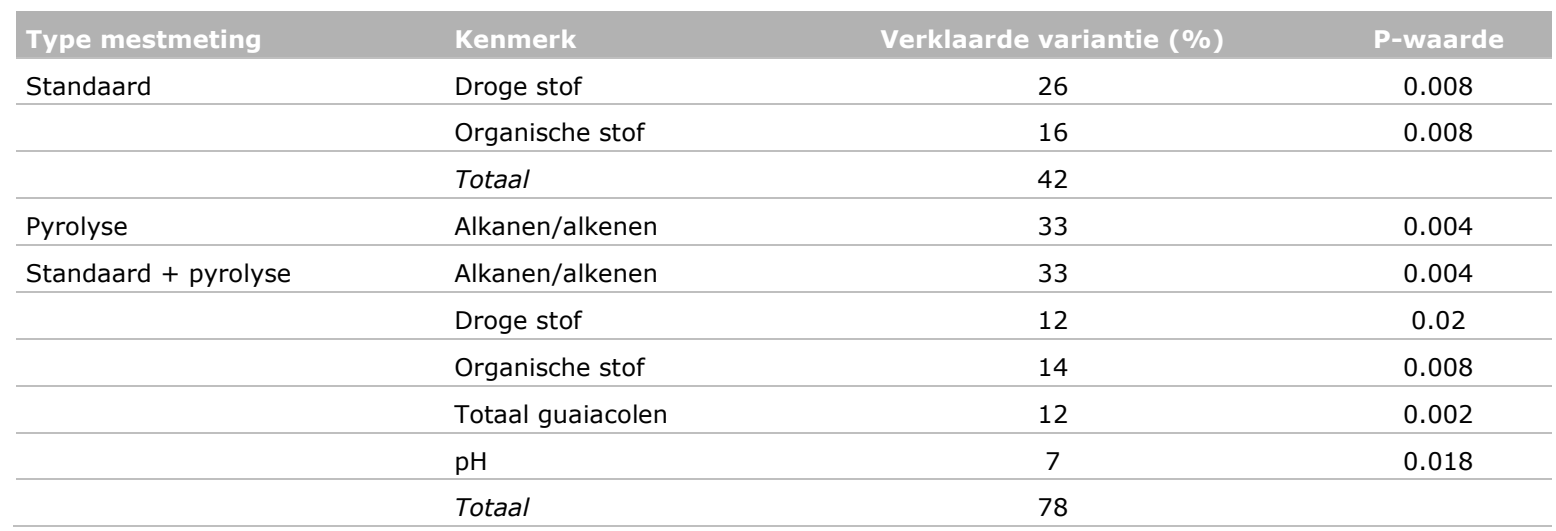

Met behulp van de modelparameters uit Tabel 3 zijn de voorspelde waarden voor totale relatieve Cmineralisatie vergeleken met de gemeten waarden (Fig. 8). Bij drie mesten week de gemeten waarde bovengemiddeld af van de voorspelde waarde. Dit betreft twee runderdrijfmesten (mestnummers 12 en 15) en een strostalmest (mestnummer 23).

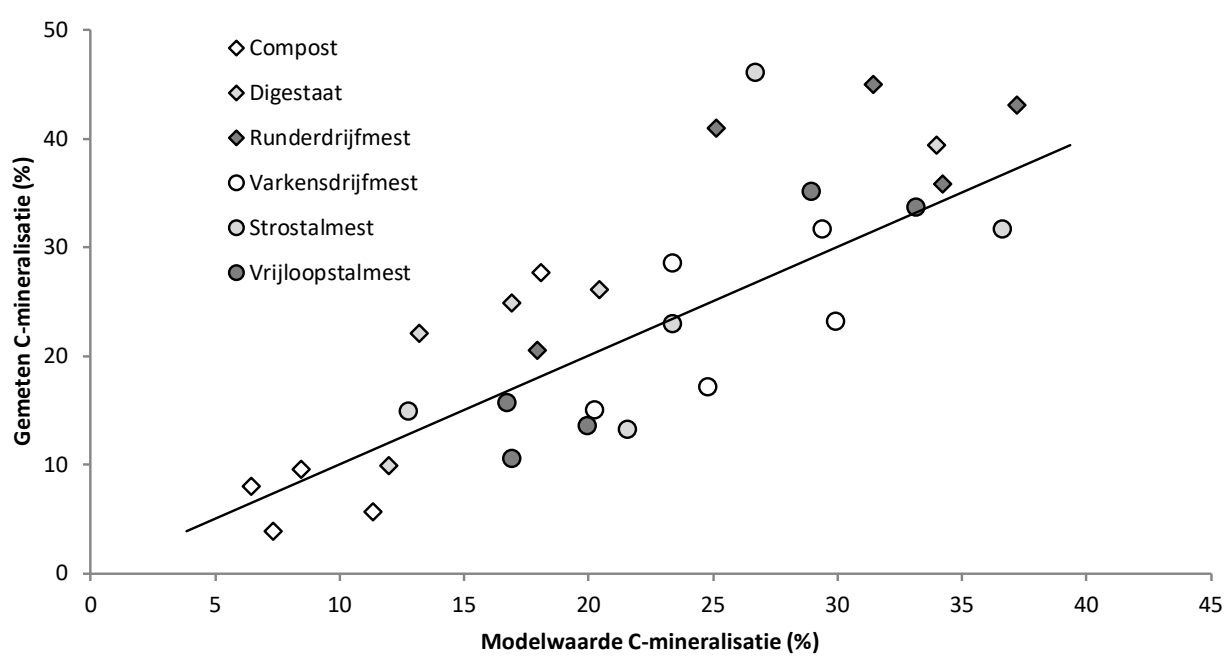

Figuur 8 De gemodelleerde versus de gemeten C-mineralisatie; modelwaarden volgen uit de parameters in Tabel 3. 


\section{Discussie}

\subsection{Spreiding in C-mineralisatie tussen mesten}

De fractie overblijvende C na 168 dagen incubatie varieerde voor alle 30 mesten tussen de $54 \%$ en 94\% (Tabel 4). Daarmee was een voldoende ruime spreiding gerealiseerd in de afbreekbaarheid van de OS. Lashermes et al. (2009) rapporteerden een ruimere spreiding van $9 \%$ en $95 \%$, voor een dataset met toediening van 83 verschillende organische producten aan 15 verschillende gronden. Deze dataset bevatte echter ook producten met een laag OS-gehalte, of relatief veel snel afbreekbare OS, zoals proceswater uit de afvalverwerking. Deze producten kunnen verantwoordelijk zijn geweest voor de (erg) lage fracties overblijvende $\mathrm{C}$.

In het voorliggende onderzoek varieerde de relatieve C-mineralisatie van de vijf runderdrijfmesten van $55 \%$ tot $79 \%$. In eerder onderzoek, bij dezelfde temperatuur en incubatieduur, varieerde de fractie overblijvende $\mathrm{C}$ van $31 \%$ tot $95 \%$, afhankelijk van de gebruikte drijfmest, zandgrond, en mestdosering (De Boer 2013, De Boer et al. 2018, De Boer 2019). In het eerdere onderzoek werd ook geconstateerd dat toediening van runderdrijfmest en andere dunne mesten aan zandgrond de mineralisatie van bodem-C kan remmen, terwijl dit bij vaste mest(fracties) niet het geval leek (De Boer et al. 2018). De oorzaak van deze remming is nog onbekend. Een dergelijke remming was in het voorliggende onderzoek niet direct zichtbaar uit het verloop van de mineralisatiecurves, maar kan desondanks wel aanwezig zijn geweest. De relatieve C-mineralisatie tussen $\mathrm{t}=112$ en $\mathrm{t}=168$ dagen was met 0,6-1,3 procentpunt erg klein, en lijkt niet conform de hoeveelheid mineralisatie die mag worden verwacht bij een ongestoord verlopende mineralisatie. Mogelijk is er ook remming opgetreden bij de C-mineralisatie uit de digestaten en varkensdrijfmesten. De C-mineralisatie van de composten, strostalmesten en vrijloopstalmesten leek wel voldoende snel te verlopen, conform eerdere resultaten (De Boer 2013, De Boer et al. 2018, Postma \& Ros 2016).

De fracties overblijvende $C$ uit het incubatieonderzoek (Tabel 4) zijn na temperatuurcorrectie (Noij et al. 1993) te vertalen naar de humificatiecoëfficiënten van de mesten: de fractie van toegediende OS die 1 jaar na toediening nog in bodem aanwezig is. Een incubatieperiode van 168 dagen bij $20^{\circ} \mathrm{C}$ komt overeen met een incubatieperiode van 331 dagen bij de gemiddelde veldtemperatuur in Nederland $\left(10,1^{\circ} \mathrm{C}\right)$. Deze periode is 34 dagen korter dan de jaarlengte van 365 dagen; de werkelijke humificatiecoëfficiënten zullen dus iets lager zijn.

\subsection{Veranderingen in pyrolyseparameters tijdens incubatie}

De resultaten van de pyrolyse werden uitgedrukt in TIC (totale ionenstroom). Deze parameter is in grote mate afhankelijk van de hoeveelheid OS die gepyrolyseerd wordt. Het lijkt daarom logisch om te veronderstellen dat door het afnemen van het OS-gehalte tijdens incubatie ook de absolute hoeveelheid TIC zou moeten afnemen. Daarmee zou een toename van het aandeel van een pyrolyseparameter in TIC mogelijk eerder geïnterpreteerd moeten worden vanuit de afname van het OS-gehalte, in plaats van als een daadwerkelijke toename in gehalte. Er is echter nog veel onduidelijk over de precieze interpretatie van TIC, en TIC kan daarom niet 1:1 gekoppeld worden aan de hoeveelheid OS in het mengsel van grond en mest. Daarmee kunnen toenames of afnames in relatieve aandelen van pyrolyseparameters op dit moment niet direct gerelateerd worden aan absolute veranderingen in OS-gehalte.

Gedurende de incubatieperiode nam het aandeel alkenen toe en het aandeel alkanen af. Deze verschuiving is niet goed te verklaren, onder andere omdat er nog veel discussie is over de herkomst van alkanen en alkenen in grond (o.a. Suárez Abelenda et al. 2011, Buurman et al. 2009, Nierop et al. 
2001). Marinari et al. (2007) zelfs plastics als mogelijke bron van alkanen en alkenen. Suárez Abelenda et al. (2011) stelt dat alkanen en alkenen afkomstig zijn van planten, en Schellekens et al. (2013) koppelt de aanwezigheid van alkanen specifiek aan afgebrand grasland. De zandgrond die werd gebruikt in de incubatieproef was afkomstig van een perceel waar voor het tweede jaar snijmaïs werd geteeld, na eerst drie jaar grasland. Er lijkt daarmee in het voorliggende experiment een link te zijn tussen de aanwezigheid van alkanen en de aanvoer van organische materiaal afkomstig van gras.

\subsection{Verklaring van C-mineralisatie uit mesteigenschappen}

In dit onderzoek wordt slechts een relatief klein deel (42\%) van de variantie in totale relatieve Cmineralisatie verklaard door de standaard mestkenmerken (Tabel 3); de toevoeging van pyrolyseparameters (de verhouding tussen alkanen en alkenen en totaal guaiacolen) aan de analyse geeft een aanzienlijke toename in verklaarde variantie, tot $78 \%$. Meting van de OS-samenstelling met pyrolyse levert daarmee in dit onderzoek een wezenlijke bijdrage aan de verklaring (en voorspelling) van de totale $\mathrm{C}$-mineralisatie, en daarmee van de $\mathrm{C}$-mineralisatie.

Met behulp van vijf variabelen kon maximaal $78 \%$ van de variantie in relatieve C-mineralisatie worden verklaard. Vijf variabelen lijkt relatief veel; Lashermes et al. (2009) konden met vier variabelen maximaal $74 \%$ van de variantie in overblijvende $C$ verklaren, ondanks dat er door hen een grotere range aan organische producten $(n=83)$ en typen grond $(n=15)$ werd gebruikt. Aantrekkelijk aan onze resultaten is dat de $78 \%$ verklaarde variantie volledig vanuit mestkenmerken verklaard kon worden. Lashermes et al. (2009) konden met behulp van mestkenmerken (ruwe-celstofanalyse) niet meer dan $54 \%$ van de variantie in overblijvende $C$ verklaren. In hun onderzoek verhoogde de toevoeging van de relatieve C-mineralisatie (in de eerste drie dagen van incubatie) als verklarende variabele de verklaarde variantie tot de genoemde $74 \%$.

Tot slot valt bij de bestudering van onze resultaten op dat het gehalte $\mathrm{N}$-totaal of gehalte minerale $\mathrm{N}$ in de mesten geen bijdrage gaf aan de verklaring van de variantie in hun C-mineralisatie, ondanks dat er bij een aantal mesten (jonge strostalmesten en vrijloopstalmesten) het minerale $\mathrm{N}$-gehalte erg laag was en er tijdens incubatie $\mathrm{N}$-immobilisatie kan zijn opgetreden. 


\section{Conclusies}

- De fractie overblijvende C na 168 dagen incubatie varieerde voor de 30 mesten tussen de 54\% en $94 \%$. Hiermee was de spreiding in afbreekbaarheid van de OS, en daarmee van verschillen in OS-kwaliteit, voldoende gerealiseerd;

- De fractie overblijvende $\mathrm{C}$ aan het einde van de incubatieperiode was gemiddeld het laagst bij de runderdrijfmesten (63\%; range 55\%-80\%) en het hoogst bij de composten ( $90 \%$; range $82 \%$ $94 \%)$;

- $\quad$ Met pyrolysemeting werden in de mengsels van grond en mest in totaal 272 pieken (pyrolysefragmenten) gedetecteerd. Hieruit konden 30 verschillende pyrolyseparameters worden onderscheiden;

- Deze set van 30 parameters was aan het einde van de incubatieperiode significant verschillend vergeleken met het begin $(P<0,001)$. Bij de hoofdgroepen guaiacolen, syringolen, en lignine was er een toename van hun aandeel in de OS, terwijl er bij de koolhydraten, stikstofcomponenten en alkanen+alkenen een afname was;

- Met alleen de standaard mestkenmerken (DS, OS) kon maximaal $42 \%$ van de variantie in totale relatieve C-mineralisatie over de incubatieperiode verklaard worden; met alleen de pyrolyseparameters (verhouding alkanen/alkenen) maximaal 33\%;

- Bij gebruik van zowel de standaard mestkenmerken als de pyrolyseparameters kon maximaal $78 \%$ van de variantie verklaard worden, door: de verhouding alkanen tot alkenen (33\%), DS $(12 \%)$, OS (14\%), totaal guaiacolen $(12 \%)$, en de $\mathrm{pH}(7 \%)$;

- $\quad$ Meting van pyrolyseparameters aan mest gaf daarmee een aanzienlijke toename van de verklaarde variantie in C-mineralisatie uit deze mest. Pyrolyse lijkt daarmee een zinvolle aanvulling op bestaande bepalingen van OS-kwaliteit in mest. 


\section{Dankwoord}

Paul Galama (WLR) en Studieclub 'Morgen' worden bedankt voor het agenderen van de noodzaak voor het opzetten van een mestwaarderingssysteem (met de kwaliteit van OS als belangrijk onderdeel), Paul Galama en Pieter de Wolf (WPR) voor het inbrengen van dit onderwerp in de PPS Beter Bodembeheer; Katrin Oltmer (Eurofins) voor het regelen van de mestverzameling;

melkveeproefbedrijf De Marke voor de mogelijkheid om grond van een maïsperceel te verzamelen; Willeke van Tintelen en Tamas Salanki (CBLB) voor uitvoer van de incubatieproeven, en Jantine van Middelkoop (WLR) en Petra van Vliet (Eurofins) voor de review van conceptversies van dit rapport.

Het onderzoek in dit rapport werd gefinancierd uit de PPS Beter Bodembeheer (Onderdeel 1b, Sturen op mestkwaliteit) (AF 16064, BO-47-001-006), met medefinanciering van ZuivelNL. 


\section{Literatuur}

De Boer HC (2013) On farm development of bedded-pack dairy barns in the Netherlands - Nutrient balances and manure quality of bedding material. Report 709, Wageningen Livestock Research

De Boer HC (2019). Afbreeksnelheid van organische stof uit runderdrijfmest: effecten van dosering, zoutgehalte, en herkomst mest en grond. Rapport 1231, Wageningen Livestock Research

De Boer HC, Timmerman M, Verdoes N, Schilder H (2018) Afbraak van organische stof uit (bewerkte) rundermest na toediening aan een zandgrond. Rapport 1095, Wageningen Livestock Research

Buurman P, Nierop KGJ, Kaal J, Senesi N (2009) Analytical pyrolysis and thermally assisted hydrolysis and methylation of EUROSOIL humic acid samples - A key to their source. Geoderma 150:10-22

Buurman P, Schellekens J Fritze HI, Nierop KGJ (2007) Selective depletion of organic matter in mottled podzol horizons. Soil Biology \& Biochemistry 39:607-621

Lashermes G, Nicolardot B, Parnaudeau V, Thuriès L, Chaussod R, Guillotin ML, Linères M, Mary $B$, Metzger L, Morvan R, Tricaud A, Villette C, Houot S (2009) Indicator of potential residual carbon in soils after exogenous organic matter application. European Journal of Soil Science 60:297-310

Marinari S, Masciandaro G, Ceccanti B, Grego S (2007) Evolution of soil organic matter changes using pyrolysis and metabolic indices: A comparison between organic and mineral fertilization. Bioresource Technology 98:2495-2502

Nierop KGJ, Pulleman MM, Marinissen JCY (2001) Management induced organic matter differentiation in grassland and arable soil: a study using pyrolysis techniques. Soil Biology \& Biochemistry 33:755764

Nierop KGJ, Van Bergen PF, Buurman P, Van Lagen B (2005) NaOH and $\mathrm{Na}_{4} \mathrm{P}_{2} \mathrm{O}_{7}$ extractable organic matter in two allophanic volcanic ash soils of the Azores Islands - a pyrolysis GC/MS study. Geoderma 127:36-51

Noij IGAM, Janssen BH, Wesselink LG, Van Grinsven JJM (1993) Modelling nutrient and moisture cycling in tropical forests. Tropenbos Series 4, The Tropenbos Foundation, Wageningen

Postma R, Ros G (2016) Bepalen van stabiliteit van GFT-en groencomposten. NMI-rapport 1580, NMI, Wageningen

Schellekens J, Barberá GG, Buurman P, Pérez-Jordà G, Martínez-Cortizas A (2013) Soil organic matter dynamics in Mediterranean A-horizons - The use of analytical pyrolysis to ascertain land-use history. Journal of Analytical and Applied Pyrolysis 104:287-298

Suárez Abelenda M, Buurman P, Camps Arbestain C, Kaal J, Martinez-Cortizas A, Gartzia-Bengoetxea $\mathrm{N}$, Macías $\mathrm{F}$ (2011) Comparing $\mathrm{NaOH}$-extractable organic matter of acid forest soils that differ in their pedogenic trends: a pyrolysis-GC/MS study. European Journal of Soil Science 62:834-848

Velthof GL, Oenema O (2010) Estimation of plant-available nitrogen in soils using rapid chemical and biological methods. Communications in Soil Science and Plant Analysis 41:52-71 


\section{Bijlage}

Tabel 4 Overblijvende hoeveelheid $C$ in mengsels van grond en mest, of alleen in mest (na correctie voor de bijdrage van grond), aan het begin en einde van een 168-dagen durende incubatieperiode.

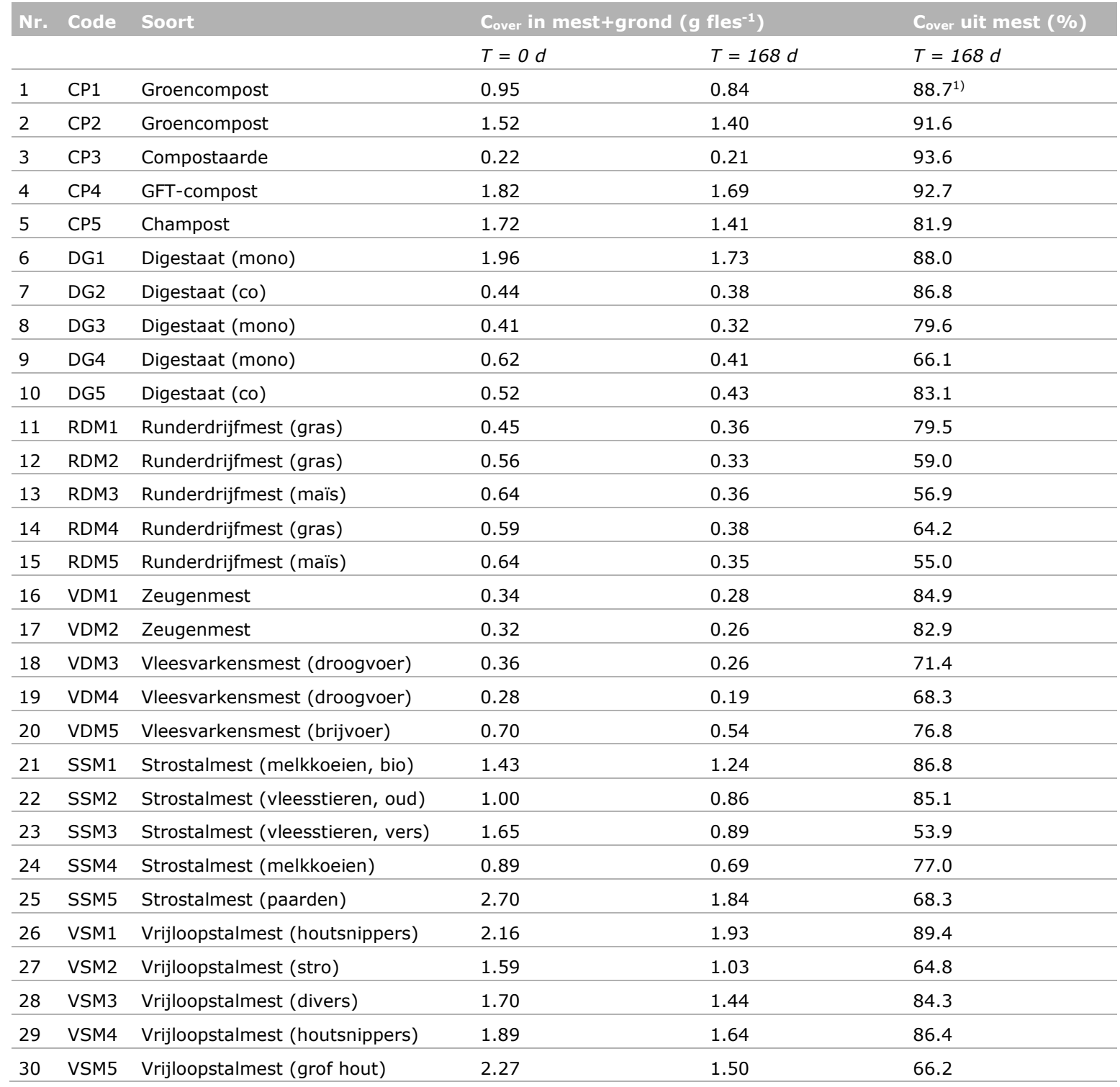

1) $\mathrm{LSD}=1.9 \%$ (bij vergelijking tussen mesten onderling, in de laatste kolom; $a=0,05$ ) 


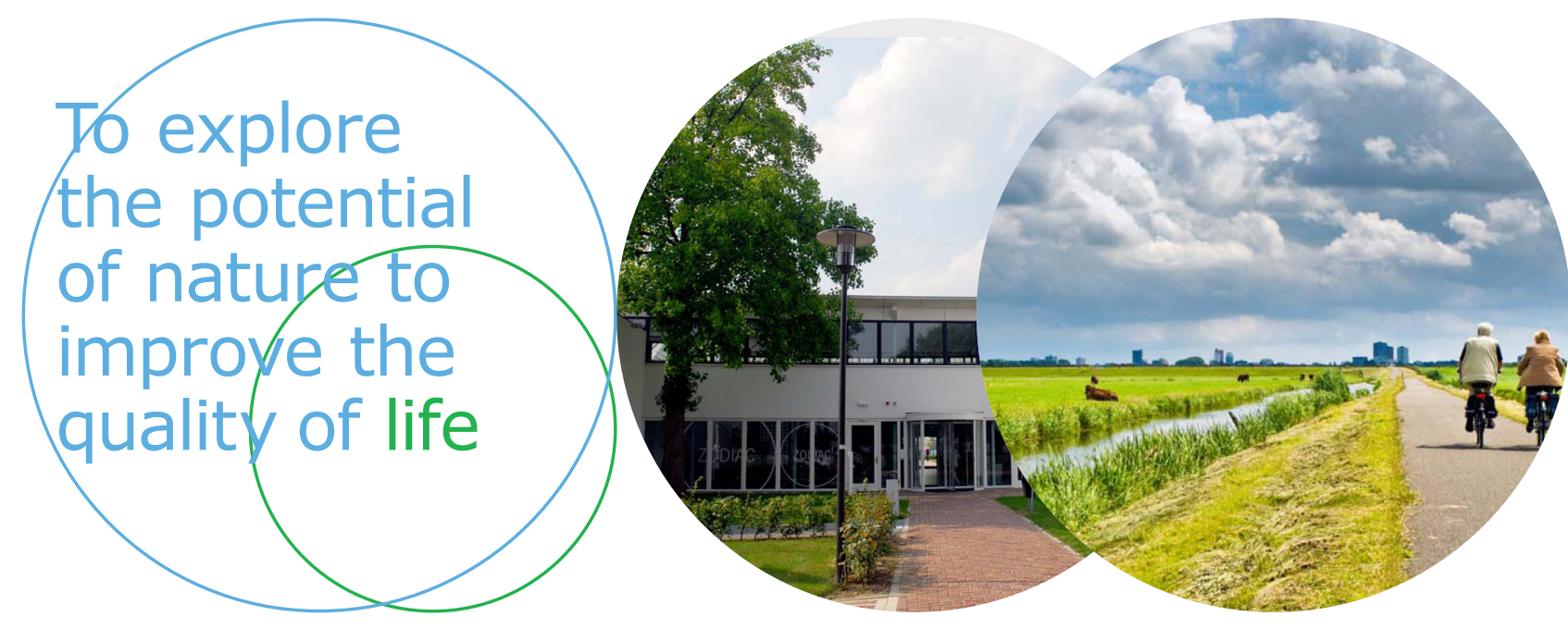

Wageningen Livestock Research Postbus 338

Wageningen Livestock Research ontwikkelt kennis voor een zorgvuldige en $6700 \mathrm{AH}$ Wageningen

T 0317483953

renderende veehouderij, vertaalt deze naar praktijkgerichte oplossingen en innovaties, en zorgt voor doorstroming van deze kennis. Onze wetenschappelijke E info.livestockresearch@wur.nl www.wur.nl/ livestock-research kennis op het gebied van veehouderijsystemen en van voeding, genetica, welzijn en milieu-impact van landbouwhuisdieren integreren we, samen met onze klanten, tot veehouderijconcepten voor de 21 e eeuw.

De missie van Wageningen University \& Research is 'To explore the potential of nature to improve the quality of life'. Binnen Wageningen University \& Research bundelen 9 gespecialiseerde onderzoeksinstituten van Stichting Wageningen Research en Wageningen University hun krachten om bij te dragen aan de oplossing van belangrijke vragen in het domein van gezonde voeding en leefomgeving. Met ongeveer 30 vestigingen, 6.500 medewerkers en 10.000 studenten behoort Wageningen University \& Research wereldwijd tot de aansprekende kennisinstellingen binnen haar domein. De integrale benadering van de vraagstukken en de samenwerking tussen verschillende disciplines vormen het hart van de unieke Wageningen aanpak. 